\title{
Nutritional studies on brewer dried grains as an alternative protein source for Nile tilapia (Oreochromis niloticus) diets.
}

\author{
Mohssen, S. Hessein ${ }^{1}$; Al-Desoki, A. M. Al-Azab ${ }^{1}$; Abd El-Wahab. A, Abd \\ El-Warith ${ }^{1}$; Medhat, E. Seden ${ }^{2}$ and Mohammed, S. A Bolbol ${ }^{1}$. \\ 1- Department of Animal Production, Faculty of Agriculture, El-Azhar University. \\ 2- Central Laboratory for Aquaculture Research, Abbassa, Sharkia, Egypt.
}

\section{ABSTRACT}

Brewer dried grain (BDG) was tested to replace soybean meal in diets of mono sex Nile tilapia (Oreochromis niloticus). Five isonitrogenous (30\%), isocaloric (442 $\mathrm{kcal} / 100 \mathrm{~g}$ ) diets were formulated to contain BDG as an alternative protein source instead of soybean meal at different levels $(0,25,50,75$ and $100 \%)$. A total number of 225 of Nile tilapia $(0.45 \mathrm{~g})$ were randomly distributed into five experimental groups, each in trireplecates, and were fed daily at a rate of $15 \%$ decreased gradually to be $4 \%$ of fish live weight through 14weeks experimental period.Data collected were on growth performance, feed utilization and body composition in addition to economic evaluation. Results of growth performance did not show any adverse effects related to the incorporation of BDG up to $75 \%$. FI shows the exact similar trend of growth performance. The incorporation of BDG in the diets improved slightly FCR, FER and PPV. Fish whole body composition of treatments groups which showed higher DM, EE, energy and somewhat protein contents and lower moisture and ash than that recorded at the start of the experiment.

Keywords: Nile tilapia, brewer dried grain, growth performance, feed utilization, body composition, economic efficiency.

\section{INTRODUCTION}

According to the UN Food and Agriculture Organization, aquaculture is growing more rapidly than all other animal food-production sectors (FAO, 2006).Tilapias are second only to carps as the most widely farmed freshwater fish in the world; three-quarters of the world's supply comes from aquaculture. World tilapia production has been increased steadily during the last decade, with output more than doubling from $931,000 \mathrm{mt}$ in 1997 to 2.3 million $\mathrm{mt}$ in 2006 (FAO, 2007a). Tilapias are the third largest group of farmed finfish species, only after carps and salmonids with an average annual growth rate of about $11.5 \%$ (FAO, 1997). About 2.3 million mt. or $99 \%$ of farmed tilapia were produced in developing countries in 2006 with Africa producing about $13 \%$ of this amount (FAO, 2007b). Egypt is the second biggest tilapia producer (202.60 mt) after China (FAO, 2007b).

The expansion of aquaculture production has been accompanied by rapid growth of aquafeed production. The challenge facing the aquaculture industry is to identify economically viable and environmentally friendly alternatives to fish meal, soybean meal and yellow corn on which many present aquafeeds are largely based.

Soybean (Glycine max) meal (SBM) hasbeen used as a major protein source in diets for aquaticanimals, especially for the replacement of fishmeal (FM), which is costlier, less available, and lesssTable in supply and price than soybean(Hertrampf and Piedad-Pascual, 2000; Chien and Chiu 2003). A significantamount of research has been conducted on the replacement of FM with SBM as protein sources in feedsfor tilapia Oreochromis spp. (Jackson, Capper \&Matty 1982;Twibell\&Brown 1998;El- 
Sayed 1999; Fontainhas Fernandes, et al., 1999) and SBM is now a major ingredient in commercialtilapia feed, and in turn numerous studies suggested good alternative vegeTable protein source instead of SBM such aslupin seed meal (Viola, et al., 1988; Fontainhas-Fernandes et al., 1999) tomato by-product (Soltan, et al., 2005) cucumber leaves, squash leaves and broad bean leaves (Magouz, et al., 2008) brewer's grains with yeast (Muzinic, et al., 2004) distillers dried grains with Solubles (Salama, et al., 2010).

This study aimed to investigate the effects of incorporation of brewer dried grain (BDG) instead of soybean meal on growth performance, feed utilization, body composition and economic efficiency of Nile tilapia.

\section{MATERIALS AND METHODS}

\section{Experimental fish and treatments:}

This study was conducted at central laboratory for fish aquaculture research, Abbassa, Abo-Hammad, Sharkia, Egypt. The experimental rearing system consisted of series $15^{\text {th }}$ glass aquaria containing $90 \mathrm{~L}$ of de-chlorinated tap water, (Five treatments in trireplecates). Fish were acclimated indoor tank for 2 weeks to laboratory conditions. Nile tilapia fry (all male) was distributed randomly, each aquaria was stocked with 15 fish with an average initial weight $0.45 \mathrm{~g} /$ fish. Each aquarium was supplied with compressed air via air-stones from air pumps, settled fish wastes were cleaned daily by siphoning of quarter of the volume, which was replaced by aerated water. The photoperiod was set on a 12-12 hour light-dark cycle using fluorescent tubes as a light source. Fish in each aquarium were weighed every two weeks.

\section{Diet preparation and feeding:}

Brewer dried grains (BDG) samples used in this study were granted fromBeer division, Al-Ahram Company of drinks, Abo-Hammad, Sharkia. The proximate composition of the ingredients used in the diets formulated is presented in Table (1). The experimental diets were prepared by fine grinding of the dietary ingredients. Thereafter, all ingredients of each experimental diet were thoroughly mixed together to get homogenous mixture. After that, the mixture was pelleted in a modified paste extruder provided with $1 \mathrm{~mm}$ die to form five experimental diets.

Table 1: Composition of the ingredients used in the experimental diet.

\begin{tabular}{|c|c|c|c|c|c|}
\hline Ingredients & FM & SBM & $\mathrm{YC}$ & PBP & $\mathrm{BDG}$ \\
\hline Dry matter $(\%)$ & 92.10 & 90.80 & 89.20 & 88.20 & 91.58 \\
\hline Crude protein $(\%)$ & 72.00 & 44.00 & 8.50 & 12.50 & 23.50 \\
\hline Lipid (\%) & 8.70 & 1.20 & 3.60 & 3.00 & 3.40 \\
\hline Crude fiber $(\%)$ & - & 5.80 & 3.20 & 11.00 & 16.30 \\
\hline NFE (\%) & 6.7 & 42.50 & 82.70 & 69.10 & 52.60 \\
\hline $\operatorname{Ash}(\%)$ & 12.60 & 6.50 & 2.00 & 5.00 & 4.20 \\
\hline Calculated composition & & & & & \\
\hline Gross energy $(\mathrm{kcal} / \mathrm{kg})^{1}$ & 5158.15 & 4299.4 & 4128.45 & 3753.05 & 3452.95 \\
\hline Digestible protein $(\%)^{2}$ & 59.69 & 34.85 & 5.81 & 10.25 & 19.34 \\
\hline Digestible energy $(\mathrm{kcal} / \mathrm{kg})^{3}$ & 3392.2 & 2699.7 & 2656.6 & 2408 & 2412.9 \\
\hline
\end{tabular}

1- Gross energy was calculated using gross calorific values of 5.65, 4 and $9.45 \mathrm{kcal} /$ gfor protein, carbohydrate and fat, respectively, according to Jobling (1983).

2- Digestible proteins were calculated using values of $82.90 \%$ for FM and $68.3 \%$ for yellow corn according to Wilson and Robinson (1982). Values of 79.2 and 82.00 were used for SBM and WB, respectively, according to Hepher (1988). Brewer dried grain was calculated using value of 82.3 according to Cheng, et al., (2004).

3- Digestible energy was calculated using values $3.5,8.1$ and $2.5 \mathrm{kcal} / \mathrm{gfor}$ protein, fat and carbohydrate, respectively according to NRC (1993). 
The five diets were approximately similar in all the nutrient contents (almost $30 \% \mathrm{CP})$ but containing different levels $(0,25,50,75$ and $100 \%)$ of BDG to replace SBM (Tables $2 \& 3$ ). Feed was given to experimental fish at a rate of $15 \%$ of the body weight; this rate was decreased gradually until to be $4 \%$ of body weight. The feeding rate was adjusted every two weeks according to the development of fish weight. The tested diets were provided two times daily at 9.00 and $15.00 \mathrm{hr}$.

Table 2: Composition of the experimental diets.

\begin{tabular}{|l|c|c|c|c|c|}
\hline \multirow{2}{*}{ Ingredients } & \multicolumn{5}{|c|}{ Diets } \\
\cline { 2 - 6 } & $\mathrm{T}_{0}$ & $\mathrm{~T}_{1}$ & $\mathrm{~T}_{2}$ & $\mathrm{~T}_{3}$ & $\mathrm{~T}_{4}$ \\
\hline Fish meal & 19.00 & 19.00 & 19.00 & 19.00 & 19.00 \\
Soybean meal & 28.00 & 21.00 & 14.00 & 7.00 & 00 \\
BDG & 00.00 & 13.11 & 26.21 & 39.32 & 52.43 \\
Yellow corn & 34.00 & 30.00 & 26.00 & 22.00 & 17.00 \\
Wheat bran & 13.00 & 10.00 & 8.00 & 6.00 & 4.00 \\
Oil & 3.00 & 3.89 & 3.79 & 3.68 & 4.57 \\
Vit\& Min* & 3.00 & 3.00 & 3.00 & 3.00 & 3.00 \\
Sum & 100 & 100 & 100 & 100 & 100 \\
\hline
\end{tabular}

*Vitamin \& mineral mixture/kg premix: Vitamin D , 0.8 million IU; A, 4.8 million IU; E, 4 g; K, 0.8 g; B1, 0.4 g; Riboflavin, 1.6 g; B6, 0.6 g,3B12, 4 mg; Pantothenic acid, 4 g; Nicotinic acid, 8 g; Folic acid, 0.4 g Biotin, 20 mg, Mn, 22 g; Zn, 22 g; Fe, 12 g; Cu, 4 g; I, 0.4 g, Selenium, 0.4 g and Co, 4.8 mg.

Table 3: Chemical composition of the experimental diets.

\begin{tabular}{|l|c|c|c|c|c|}
\hline \multirow{2}{*}{ ingredients } & \multicolumn{5}{|c|}{ diets } \\
\cline { 2 - 6 } & $\mathrm{T}_{0}$ & $\mathrm{~T}_{1}$ & $\mathrm{~T}_{2}$ & $\mathrm{~T}_{3}$ & $\mathrm{~T}_{4}$ \\
\hline $\mathrm{DM}$ & 90.95 & 90.97 & 90.99 & 90.96 & 90.98 \\
$\mathrm{CP}$ & 30.95 & 30.5 & 30.25 & 29.96 & 29.5 \\
$\mathrm{EE}$ & 6.69 & 7.53 & 8.11 & 8.75 & 9.25 \\
$\mathrm{CF}$ & 4.50 & 5.47 & 6.82 & 8.15 & 9.5 \\
$\mathrm{ASH}$ & 6.8 & 6.73 & 6.68 & 6.52 & 6.39 \\
$\mathrm{NFE}$ & 51.06 & 49.77 & 48.14 & 46.62 & 45.36 \\
\hline \multicolumn{6}{|c|}{ Calculated values } \\
\hline $\mathrm{GE} \mathrm{(kcal/100g)})^{1}$ & 442.33 & 442.56 & 440.11 & 438.44 & 435.53 \\
$\mathrm{DE} \mathrm{(kcal/100g)}$ & 331.75 & 331.92 & 330.08 & 328.83 & 326.65 \\
$\mathrm{ME} \mathrm{(kcal/100g)}$ & 371.66 & 371.94 & 369.82 & 368.40 & 365.98 \\
$\mathrm{P} / \mathrm{E} \mathrm{ratio}^{4}$ & 69.97 & 68.92 & 68.73 & 68.33 & 67.73 \\
\hline
\end{tabular}

1- Gross energy, according to Jobling (1983).

2- Digestible energy calculated as $75 \%$ of the gross energy Jobling, (1983).

3- Metabolizable energy calculated using values $4.5,8.1$ and $3.49 \mathrm{kcal} / \mathrm{gfor}$ protein, fat and carbohydrate, respectively according to Pantha, (1982).

4- $\mathrm{P} / \mathrm{E}$ ratio $=\mathrm{mg}$ crude protein $/ \mathrm{kcal} \mathrm{GE}$.

\section{Growth performance and feed utilization parameters:}

At the termination of the experimental period final body weight (FBW), body weight gain (BWG), specific growth rate (SGR), relative growth rate (RGR), feed conversion ratio (FCR), protein efficiency ratio (PER), protein productive value (PPV) and energy utilization (EU) were calculated according to the following equations:-

1- Total weight gain $=$ final weight $(\mathrm{g})$ - initial weight $(\mathrm{g})$.

2- Relative growth rate $=$ final weight $(\mathrm{g})$ - initial wt $(\mathrm{g}) /$ initial wt $(\mathrm{g})$

3- SGR = Ln W2- Ln W1 / T X 100, Where: W2=final weight, W1 = Initial weight, $\mathrm{T}=$ periods in days, $\mathrm{Ln}=$ Natural logarithm.

4- FCR $=$ Feed intake $/$ Weight gain 
5- $\mathrm{PER}=\mathrm{W}$ gain $(\mathrm{g}) /$ protein consumed (intake) $(\mathrm{g}) \mathrm{x} 100$.

$6-\mathrm{PPV} \%=100$ [final fish body protein $(\mathrm{g})$ - initial fish body protein $(\mathrm{g}) /$ crude protein intake $(\mathrm{g})]$.

7- EU \% = 100[final body energy $(\mathrm{K} \mathrm{Cal})$ - initial body energy $(\mathrm{K} \mathrm{Cal}) /$ energy intake $(\mathrm{K} \mathrm{Cal})]$

\section{Chemical and statistical analysis:}

Diets and fish samples were analyzed according to AOAC (1990) for moisture, protein, fat and ash. Metbolizable energy calculated according to Jauncey (1982). The obtained numerical data were statistically analyzed using SPSS (1997) for one-way analysis of variance. When F-test was significant, least significant difference was calculated (Duncan, 1955).

\section{RESULTS AND DISCUSSION}

\section{Chemical composition:}

Compared with SBM, BDG (Table1) have the following disadvantages: lower protein content, lower gross energy and higher fibre. As described in this Table therelatively high protein content of BDG indicate the possibility of incorporation of this cheap industrial by-product in fish diets as a replacement of the coasty SBM, moreover EE content in BDG is higher than that of SBM. BDG fiber content is higher than that of SBM, so it may be act as a negative factor on both growth performance and feed utilization (De Silva and Anderson, 1995). BDG has admirable essential amino acids profile comparing to that of both SBM and the profile concluded by Santiago and Lovell (1988) for tilapia except for lysine, methionine and somewhat threonine and tryptophan.

\section{Growth performance:}

The growth performance parameters of Nile tilapia fed the experimental diets are shown in Table (4). The initial weight of fish groups are equal indicating the homogeneity of distribution. By the termination of the feeding period (98 days), fish fed tested diets revealed insignificant differences $(\mathrm{P}>0.05)$ for final body weight, body weight gain up to $75 \%$ replacement level, in spiteof veryminor reduction in FBW and BWG. Also, SGR and RGR values however recorded some decreases but it still insignificant $(\mathrm{P}>0.05)$ for all treatment groups compared to the control.

Table 4: Effect of replacement of soybean meal protein with BDG on growth performance parameters of Nile tilapia.

\begin{tabular}{|l|c|c|c|c|c|}
\hline \multicolumn{7}{|c|}{ Experimental diets } \\
\hline Parameters & $\mathrm{T}_{0}$ & $\mathrm{~T}_{1}$ & $\mathrm{~T}_{2}$ & $\mathrm{~T}_{3}$ & $\mathrm{~T}_{4}$ \\
\hline IW (g/fish) & 0.44 & $0.45^{\mathrm{a}}$ & $0.45^{\mathrm{a}}$ & $0.45^{\mathrm{a}}$ & $0.45^{\mathrm{a}}$ \\
& \pm 0.03 & \pm 0.01 & \pm 0.00 & \pm 0.02 & \pm 0.03 \\
FW (g/fish) & $16.52^{\mathrm{a}}$ & $16.23^{\mathrm{ab}}$ & $15.89^{\mathrm{ab}}$ & $16.23^{\mathrm{ab}}$ & $14.65^{\mathrm{b}}$ \\
& \pm 0.08 & \pm 0.05 & \pm 0.79 & \pm 0.09 & \pm 0.09 \\
BWG (g/fish) & $16.05^{\mathrm{a}}$ & $15.78^{\mathrm{ab}}$ & $15.44^{\mathrm{ab}}$ & $15.78^{\mathrm{ab}}$ & $14.2^{\mathrm{b}}$ \\
& \pm 0.8 & \pm 0.04 & \pm 0.79 & \pm 0.01 & \pm 0.06 \\
SGR (\%) & $3.67^{\mathrm{a}}$ & $3.66^{\mathrm{a}}$ & $3.64^{\mathrm{a}}$ & $3.66^{\mathrm{a}}$ & $3.56^{\mathrm{a}}$ \\
& \pm 0.03 & \pm 0.03 & \pm 0.05 & \pm 0.04 & \pm 0.06 \\
RGR (\%) & $3624^{\mathrm{a}}$ & $3509^{\mathrm{a}}$ & $3436^{\mathrm{a}}$ & $3516^{\mathrm{a}}$ & $3180^{\mathrm{a}}$ \\
& \pm 44 & \pm 82 & \pm 175 & \pm 137 & \pm 192 \\
\hline
\end{tabular}

$a, b, \ldots$ etc.: Means within row with different superscripts are significantly different $(\mathrm{P}<0.05)$

Unfortunately, Published data on the use of brewer's grains in aquaculture diets are limitedhowever Brewer's grains doesnot have any known anti-nutritional factors, 
such as gossypol Muzinica, et al. (2004), this property may be due to the proceduresto which barley were subjected (steeping, heating and enzyme treats) during the production of beer (Hough, 1985; El-Boushy and Van der Poel, 1994) these procedures collectively the common recommended processing techniques for removing anti-nutritional factors as reported by Francis, et al., (2001). So, the cause of the minor reduction in the growth performance concurrent with low substitution levels and more pronounced in the high one $(100 \%)$, may be constrained by both the higher fiber content and the lower gross energy content compared to SBM. This is in agreement with Grant (1985) who evaluated the potential brewer's grain meal (BGM) as a diet ingredient for rainbow trout, Ingredient levels were varied in isonitrogenous and isocaloric diets containing $0,9.3 \%, 18.7 \%, 28.0 \%$, and $37.3 \%$ BGM, respectively (up to $100 \%$ replacement of plant protein namely, soybean and cottonseed meals). After the 66-day feeding trial, rainbow trout had no differences in weight gains, feed conversion ratios, and percentage survival among treatments, thereafterhe concluded that BGM was a good diet ingredient for rainbow trout that could replace soybean and cottonseed meals at relatively high levels (37\%). Salama, et al., (2010) used distillers dried grains with soluble (DDGS) instead of soybean in diets for Nile tilapia. They found that growth performance recorded significant improvements by different degrees up to $80 \%$ replacement level compared with the control. Moreover, Muzinica, et al. (2004) found that a combination of soybean meal and brewer's grains with yeast (BGY) could be totally replacing fish meal in red claw crayfish diets without any significant effects on final weight, weight gain, or survival.

\section{Feed utilization:}

As described in Table (5) FI recorded insignificant difference $(\mathrm{P}>0.05)$ between treatments up to $75 \%$ replacement level, $\mathrm{T}_{2}(25 \%)$ recorded the best FI value while $\mathrm{T}_{4}$ $(100 \%)$ recorded the poorest one. Concerning to FCR, PER and PPV results exhibited insignificant differences $(\mathrm{P}>0.05)$ for all treatments comparing to the $\mathrm{T}_{0}$ (control) with slight improvement for $\mathrm{T}_{1}(25 \%), \mathrm{T}_{2}(50 \%)$ and $\mathrm{T}_{4}(100 \%)$ respectively. Energy utilization exhibited fluctuated results collectively positive, $\mathrm{T}_{2}$ and $\mathrm{T}_{4}$ recorded significant improvement $(\mathrm{P}<0.05)$, while $\mathrm{T}_{1}$ and $\mathrm{T}_{3}$ did not reveal any adverse effects compared to the control.

Table 5: Effects of replacement of soybean meal protein with BDG on feed utilization parameters of Nile tilapia.

\begin{tabular}{|l|c|c|c|c|c|}
\hline \multirow{2}{*}{ Treatment } & & \multicolumn{4}{|c|}{$\mathrm{BDG}$} \\
\cline { 2 - 6 } & $\mathrm{T}_{0}$ & $\mathrm{~T}_{1}$ & $\mathrm{~T}_{2}$ & $\mathrm{~T}_{3}$ & $\mathrm{~T}_{4}$ \\
\hline FI (g/fish) & $28.28 \pm 0.08^{\mathrm{a}}$ & $27.74 \pm 1.43^{\mathrm{ab}}$ & $26.02 \pm 0.56^{\mathrm{ab}}$ & $28.63 \pm 1.43^{\mathrm{a}}$ & $24.32 \pm 0.21^{\mathrm{b}}$ \\
FCR & $1.77 \pm 0.12^{\mathrm{a}}$ & $1.76 \pm 0.05^{\mathrm{a}}$ & $1.68 \pm 0.04^{\mathrm{a}}$ & $1.81 \pm 0.04^{\mathrm{a}}$ & $1.71 \pm 0.06^{\mathrm{a}}$ \\
PER & $2.01 \pm 0.05^{\mathrm{a}}$ & $2.05 \pm 0.09^{\mathrm{a}}$ & $2.17 \pm 0.06^{\mathrm{a}}$ & $2.02 \pm 0.08^{\mathrm{a}}$ & $2.17 \pm 0.06^{\mathrm{a}}$ \\
PPV\% & $33.07 \pm 1.0^{\mathrm{a}}$ & $33.14 \pm 1.93^{\mathrm{a}}$ & $35.58 \pm 0.97^{\mathrm{a}}$ & $34.13 \pm 0.8^{\mathrm{a}}$ & $36.60 \pm 1.35^{\mathrm{a}}$ \\
EU\% & $21.10 \pm 0.71^{\mathrm{b}}$ & $19.20 \pm 0.76^{\mathrm{b}}$ & $23.57 \pm 0.38^{\mathrm{a}}$ & $21.17 \pm 0.13^{\mathrm{b}}$ & $23.41 \pm 0.88^{\mathrm{a}}$ \\
\hline
\end{tabular}

$\mathrm{a}, \mathrm{b}, \ldots$ etc.: Means within row with different superscripts are significantly different $(\mathrm{P}<0.05)$

The previous results are in accordance with Salama, et al., (2010) detected that feed intake increased gradually and significantly with increasing (DDGS) up to $100 \%$. Also they found that the lower substitution levels 20, 40\% recorded the best FCR, PPV and EU values than the higher ones $(60,80$ and 100\%) but the opposite trend was observed with PER. Soltan (2002) and Soltan, et al., (2005) reported that increasing the levels of TBM as a replacement of SBM in tilapia and common carp diets respectively up to $50 \%$ had no significant effects on either FCR or PER. 


\section{Whole body chemical composition:}

The chemical composition of the whole body of fish fed the experimental diets is presented in Table (6). Dry matter showed no hassignificant differences between the treatments associated with replacement process. Protein content demonstrated an improvement for all treatments; these improvements are significant only for $T_{1}$ and are not for the others. Fat content revealed improvements with the increase of BDG levels, except for $T_{1}$ which recorded significant decrease. Ash content tends to decrease significantly with theincrease of substitution levels except for $T_{1}$.

Table 6: Chemical composition and energy contents of tilapia carcass as affected by diets with BDG.

\begin{tabular}{|l|l|l|l|l|l|l|}
\hline \multirow{2}{*}{ parameters } & \multicolumn{7}{|c|}{ Diets } \\
\cline { 2 - 7 } & \multicolumn{1}{|c|}{ initial } & \multicolumn{1}{|c|}{$\mathrm{T}_{0}$} & \multicolumn{1}{c|}{$\mathrm{T}_{1}$} & \multicolumn{1}{c|}{$\mathrm{T}_{2}$} & $\mathrm{~T}_{3}$ & $\mathrm{~T}_{4}$ \\
\hline $\mathrm{DM}$ & 20.16 & $26.39 \pm 0.7^{\mathrm{a}}$ & $25.29 \pm 0.73^{\mathrm{a}}$ & $26.60 \pm 0.84^{\mathrm{a}}$ & $26.21 \pm 0.18^{\mathrm{a}}$ & $26.82 \pm 0.5^{\mathrm{a}}$ \\
$\mathrm{CP}$ & 58.71 & $61.66 \pm 1.21^{\mathrm{b}}$ & $65.18 \pm 0.41^{\mathrm{a}}$ & $61.23 \pm 0.74^{\mathrm{b}}$ & $63.78 \pm 0.68^{\mathrm{ab}}$ & $62.07 \pm 0.57^{\mathrm{b}}$ \\
$\mathrm{EE}$ & 11.32 & $22.45 \pm 0.11^{\mathrm{b}}$ & $18.41 \pm 0.5^{\mathrm{c}}$ & $25.58 \pm 0.74^{\mathrm{a}}$ & $22.94 \pm 0.85^{\mathrm{ab}}$ & $24.62 \pm 0.42^{\mathrm{ab}}$ \\
Ash & 29.97 & $15.86 \pm 1.26^{\mathrm{a}}$ & $16.51 \pm 0.1^{\mathrm{a}}$ & $13.21 \pm 0.14^{\mathrm{b}}$ & $13.30 \pm 0.16^{\mathrm{b}}$ & $13.31 \pm 0.17^{\mathrm{b}}$ \\
Energy* & 437.99 & $559.70 \pm 7.37^{\mathrm{b}}$ & $541.35 \pm 2.48^{\mathrm{c}}$ & $586.77 \pm 2.98^{\mathrm{a}}$ & $576.30 \pm 4.16^{\mathrm{a}}$ & $582.49 \pm 0.96^{\mathrm{a}}$ \\
\hline
\end{tabular}

a, b, c...etc.: Means within row with different superscripts are significantly different $(\mathrm{P}<0.05)$

*Gross energy (kcal/100g) calculated according to Jobling (1983).

Energy content recorded significant improvement compared to the control $\left(\mathrm{T}_{0}\right)$ for $T_{2}, T_{4}$ and $T_{3}$ respectively, while $T_{1}$ recorded the least energy content with significant decease with all other treatments. These results are partially in agreement with the results of Salama, et al., (2010) who reported that the gradual increase in the replacement level of DDGS instead of SBM protein up to $40 \%$ resulted in gradual increase in fish body content of dry matter, crude protein, ether extract and energy content while, ash content decreased. Also, Lim, et al., (2008) and Tahoun, et al., (2009), moreover, Carl et al., (1993) found that the increase in the replacement level of DDGS instead of SBM protein up to $30 \%$ increased EE content. Teles, and Gonçalves, (2001) evaluated the effects of partial replacement of fishmeal by brewer's yeast. They reported that, no significant differences in whole body composition among experimental groups except for the protein content which was significantly higher in fish fed the brewer's yeast containing diets than the control diet.

\section{Economic evaluation:}

Feed cost is considered to be the highest recurrent cost in aquaculture, often ranging from $50 \%$ to $60 \%$ depending on the intensity of the operation. Any reduction in feed costs either through diet development, improved husbandry or other direct or indirect means is therefore crucial to the development and well-being of the industry.

The economic parameters of the tested diets are presented in Table (7).

The calculated figures showed that the cost of one ton of feed mixture was reduced in all levels of SBM substituted by BDG.

Table 7: Economical study of feeding of Nile tilapia fed diets containing graded levels of BDG.

\begin{tabular}{|c|c|c|c|c|c|}
\hline \multirow[b]{2}{*}{ Item } & \multicolumn{5}{|c|}{ diets } \\
\hline & $\mathrm{T}_{0}$ & $\mathrm{~T}_{1}$ & $\mathrm{~T}_{2}$ & $\mathrm{~T}_{3}$ & $\mathrm{~T}_{4}$ \\
\hline Costs, LE/ton & 4395 & 4198 & 3947 & 3695 & 3488 \\
\hline Decrease in feed cost (LE). & & & & & \\
\hline Consumed feed to produce $1 \mathrm{~kg}$ fish $(\mathrm{kg})$. & 00 & 4.48 & 10.19 & 15.93 & 20.64 \\
\hline Feed cost/Kg gain. & $\begin{array}{l}1.71 \\
7.78\end{array}$ & $\begin{array}{l}1.71 \\
7.39\end{array}$ & $\begin{array}{l}1.64 \\
6.63\end{array}$ & $\begin{array}{l}1.76 \\
6.68\end{array}$ & $\begin{array}{l}1.66 \\
5.96\end{array}$ \\
\hline
\end{tabular}

However, the control diet recorded the highest price being 4395L.E/ ton, while, for BDG the cost of feed mixture was 4198, 3947, 3695 and $3488 \mathrm{~L}$.E/ ton for 25, 50, 
75 and $100 \%$ BDG substitution level respectively. By calculation, $\mathrm{T}_{0}$ showed the high feed cost needed for producing one $\mathrm{Kg}$ fish gain $(7.78 \mathrm{~L}$.E) while the lowest feed cost (5.96 L.E) for one $\mathrm{Kg}$ fish gain was obtained when SBM was completely replaced by BDG. Relatively, the decreasing rate in feed cost to obtain one $\mathrm{Kg}$ fish gain increased gradually as the substitution level of BDG increased from 25 to $100 \%$. This confirms the previous obtained finding that BDG could be included safely and economically in fish diets to replace up till $75 \%$ of SBM, These results was confirmed by the findings of Soltan (2002), Soltan et al., (2005) and Salama, et al., (2010).

\section{REFERENCE}

AOAC (1990). Association of Official Analytical Chemists. Official Methods of Analysis. $15^{\text {th }}$ Ed. Published by the North Nineteen St. Aute 210 Arlingth, Virginia, 2220/USA.

Carl, D. W.; Tidwell, J. H. and Goodgame, L. S. (1993). Growth, composition, and organoleptic evaluation of channel catfish fed diets containing different percentages of distiller grains with Solubles. The progressive fuhcullurist, 55:95-100.

Cheng, Z. J.; Hardy, R. W. and Huige, N. J. (2004). Apparent digestibility coefficients of nutrients in brewer's and rendered animal by-products for rainbow trout (Oncorhynchus mykiss). Aqua. Res, 35: 1-9.

Chien, Y. H. and Chiu, Y. H. (2003). Replacement of soybean (Glycine max (L.) Merrill) meal by lupin (Lupinusangustifolius) seed meal in diet for juvenile tilapia (Oreochromis niloticus \& O. aureus) reared indoors. Aqua. Res, 34: 1261-1268.

De silva, S. S. and Anderson, T. A. (1995). Fish Nutrition in Aquaculture. Chapman and Hall, New York, 319 pp.

Duncan, D. B. (1955). Multiple Ranges and Multiple F-test. Biometerics, 11: 1-42.

El-Boushy, A. R.; Van der Poel, A. F. B. (1994). Poultry Feeding from Waste: Processing and Use. Chapman and Hall, London, Uk, p 139.

El-Sayed A. F. M. (1999). Alternative dietary protein sources for farmed tilapia, Oreochromis spp. Aqua, 179: 149-168.

FAO (2006). FAOSTAT Online Statistical Service. Rome, Italy: Food and Agriculture Organization of the United Nations.

FAO (2007a). Fishstat Plus: Universal software for fishery statistical time series. Version 2.3. 2000. Rome, Italy: Food and Agriculture Organization of the United Nations. Fisheries Department, Fishery Information, Data and Statistics Unit.

FAO (2007b). The State of World Fisheries and Aquaculture (SOFIA) 2006. World review of fisheries and aquaculture. Rome, Italy: Food and Agriculture Organization of the United Nations.

Fontainhas-Fernandes, A.; Gomes, E.; Reis-Henriques, M. A and Coimbra J. (1999). Replacement of fish meal by plant proteins in the diet of Nile tilapia: digestibility and growth performance. Aqua. Inter, 7: 57-67.

Francis, G.; Makkar, P. S. and Becker, K. ( 2001). Antinutritional factors present in plant-derived alternate fish feed ingredients and their effects in fish. Aqua, 199:197-227.

Grant, B. F. (1985). Brewer's grain meal in trout feeds. Contract Research Report to the Miller Brewing from the International Aquaculture Research Center, Hagerman, Idaho, USA. 
Haugh, J. S. (1985). The Biotechnology of Malting and Brewing.Cambridge University Press, Cambridge, London, New York, p. 168.

Hepher, B. (1988). Nutrition of Pond Fishes. Cambridge University Press, New York, USA.

Hertrampf, J.W. and Piedad-Pascual, F. (2000). Handbook on Ingredients for Aquaculture Feeds. The Netherlands: Kluwer Academic Publishers.

Jackson A. J., Capper B. S. and Matty A. J. (1982). Evaluation of some plant proteins in complete diets for the Tilapia (Sarotherodonmoss ambicus). Aqua., 27: 97-109.

Jauncey, K. (1982). The effect of varying dietary protein level on the growth, food conversion, protein utilization and body composition of juvenile tilapia, (Sarotherodmmoss ambicus). Aqua., 27: 43-54.

Jobling, M. (1983). A short review and critique of methodology used in fish growth and nutrition studies. J. Fish Biol., 23: 685-705.

Lim, C. E.; Webster, C. D. and Lee, C. S. (2008). Alternative protein sources in aquaculture diets. New York: Haworth Press., 571p.

Magouz, F. I.; EL-Gendi, M. O.; Salem, M. F. I. and ELazab, A. A. (2008). Using of cucumber, squash and broad bean leaves as non-conventional plant protein sources in Nile tilapia (Oreochromis niloticus) diets. $8^{\text {th }}$ international symposium on tilapia in aqua., 847-859.

Muzinica, L. A.; Thompsona, K. R.; Morrisa, A.; Webstera, C. D.; Rouseb, D. B and Manomaitisb, L. (2004). Partial and total replacement of fish meal with soybean meal and brewer's grains with yeast in practical diets for Australian red claw crayfish Cheraxquadricarinatus. Aqua., 230: 359-376.

NRC (1993). Composition of feed ingredients, pp. 64-72.

Pantha, M. B. (1982). The use of soybean in practical feeds for tilapia (Oreochromis niloticus L.). M. Sc. thesis Univ, of sterling.

Salama, F. A.; Tonsy, H. D.; Labib, E. M.; Mahmoud, S. H. and Zaki, M. A. (2010). Nutritional studies on partial and total replacement of soybean meal by distiller's dried grain with soluble (DDGS) in diets for Nile tilapia (Oreochromis niloticus). Egypt. J. Nutr and feeds, 13 (1): 165-176.

Santiago, C.B. and Lovell, R.T. (1988). Amino acid requirements for growth of Nile tilapia. J. Nutr., 118: 1540-1546.

Soltan, M. A. (2002). Using of tomato and potato by- products as non-conventional ingredients in Nile tilapia, Oreochromis niloticus diets. Annals of Agric. Sci., Moshtohor, 40 (4):2081-2096.

Soltan. M. A.; Abdella, M. M.; Abou-Seif, R. A. and Hassan, M. S. (2005). Using of tomato and potato by-products as partial replacements for soybean and yellow corn in practical diets for the common carp, Cyprinuscarpio. Egyp. J. Nut.and feeds, 8 (2): 257-272.

SPSS (1997). Statistical package for the social science, Revision 6, spssInc, Chicago, USA.

Tahoun, A. M.; Abo-State, H. A. and Hammouda, Y. A. (2009). Effect of adding commercial phytase to DDGS based diets on the performance and feed utilization of Nile tilapia (Oreochromis niloticus) fingerlings. AmericanEurasian J. Agric. \& Environ. Sci., 5(4): 550-555.

Twibell R. G. and Brown P. B. (1998). Optimal dietary protein concentration for hybrid tilapia (Oreochromis niloticus \& O. aureus) fed all-plant diets. J. World Aqua. S., 29: 9-16. 
Viola, S.; Arieli, Y. and Zohar, G. (1988). Unusual feedstuffs (tapioca and lupin) as ingredients for carp and tilapia feeds in intensive culture. Isr. J. Aqua., 40: 29-34.

Wilson, R. P. and Robinson, E. H. (1982). Protein and amino acid nutrition for channel catfish. Mississippi Agricultural and Forestry Experiment Station Information Bulletin, p. 25.

$$
\begin{aligned}
& \text { ARABIC SUMMARY } \\
& \text { دراسات غذائيه على تفلة البيره كمصدر بروتين بديل في علائق البلطى النيلى }
\end{aligned}
$$

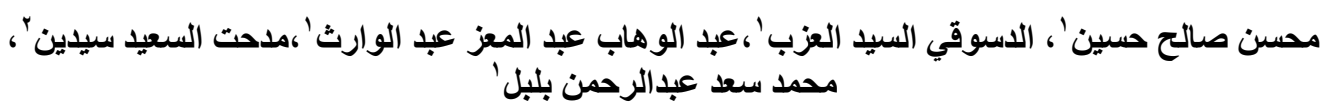

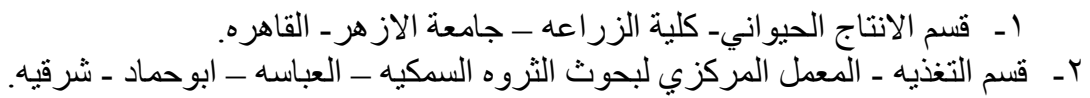

$$
\begin{aligned}
& \text { اجريت هذه التجربه لدر اسة تأثير الاحلال الكلي لكسب فول الصويا بمخلفات صناعة البيره في علائق }
\end{aligned}
$$

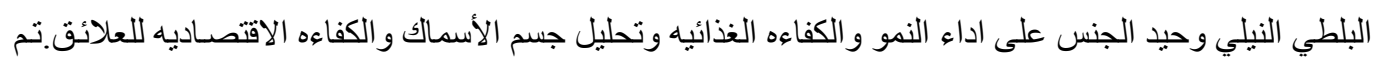

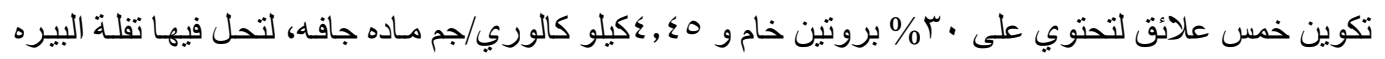

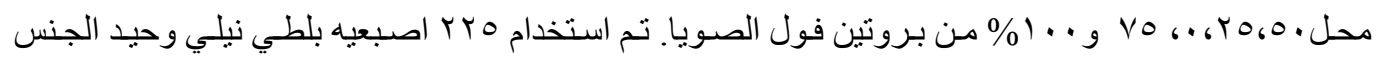

$$
\begin{aligned}
& \text { (0.45جم) وزعت عشو ائيا في خمس مجمو عات تجريبيه كل منها في ثنلاث مكررات. معدل التغذيه اليومي بدأ }
\end{aligned}
$$

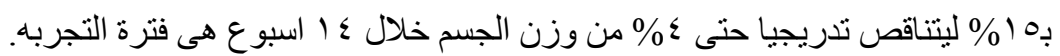

$$
\begin{aligned}
& \text { وقد اظهرت النتائج ان عملية الاستبدال لم يكن لها ابي تاثير ضـار على كل من آداء النمو او الغذاء } \\
& \text { المستهلك مع تحسن في كل من معامل التحويل الغذائي، كفاءة استخدام الغذاء و الكفاءة النسبيه للبروتين. بالنسبه }
\end{aligned}
$$

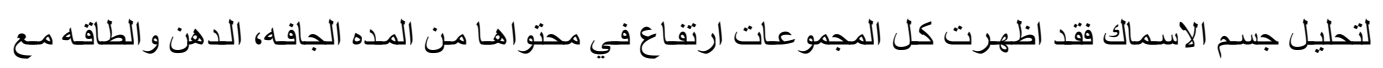

$$
\begin{aligned}
& \text { انخفاض في نسبة الرطوبه و الرماد مقارنة بما كانت عليه في بداية التجربه. }
\end{aligned}
$$

